\title{
CROWDFUNDING FOR DEVELOPING WAQF LAND A STUDY ON MALAYSIA
}

\section{CROWDFUNDING UNTUK PENGEMBANGAN WAKAF TANAF STUDI DI MALAYSIA}

\author{
MI.Hapsari'1a, M. Asmy², MO. Muhammed'2, J. Duasa' \\ ${ }^{1}$ Department of Economics, International Islamic University Malaysia, Malaysia \\ Departemen Ekonomi Syariah, Universiitas Airlangga, Indonesia \\ 2Department of Economics, International Islamic University Malaysia, Malaysia \\ aKorespondensi: Meri Indri Hapsari E-mail: meri.indri@gmail.com
}

\begin{abstract}
This present study aims to develop an alternative model of financing that address the problems of waqf land financing in Malaysia, analyse the probability that waqf institution will use the proposed model and recommend policies to enhance the optimisation of crowdfunding for developing waqf land. This study focuses on potential donors in the four states in Malaysia, namely Pahang, Pulau Pinang, Selangor and Johor since these areas have significant waqf lands. The analysis is conducted using statistical analysis and logistic regression analysis. The study finds that there is a high probability of donors willing to use the proposed model (CWM), particularly among non-married donors, females, low-middle income donors, and those with more awareness of crowdfunding and waqf.
\end{abstract}

Keywords: The Donors, Crowdfunding, Waqf Land, Logistic Regression, Malaysia

\begin{abstract}
ABSTRAK
Penelitian ini bertujuan untuk mengembangkan model pembiayaan alternatif untuk mengatasi masalah pembiayaan wakaf tanah di Malaysia, menganalisis kemungkinan lembaga wakaf akan menggunakan model yang diusulkan dan merekomendasikan kebijakan untuk meningkatkan crowfunding dalam mengembangkan wakaf tanah. Studi ini fokus pada donor yang potensial dari empat negara bagian di Malaysia yaitu Pahang, Pulau Pinang, Selangor dan Johor karena daerah-daerah ini memiliki wakaf tanah yang signifikan Analisis dilakukan dengan menggunakan analisis statistika dan regresi logistik. Hasil penelitian menunjukkan bahwa kemungkinan tinggi donatur yang menggunakan model yang diusulkan (CWM), khususnya diantara donor yang belum menikah, wanita, donor yang berpenghasilan menengah, dan yang memiliki pengetahuan tentang crowdfunding dan wakaf.
\end{abstract}

Kata kunci: Donatur, Crowdfunding, Wakaf Tanah, Regresi Logistik, Malaysia

Hapsari MI. 2020. Crowfunding For Developing Waqf Land A Study On Malaysia. Jurnal Syarikah 6(1): 1-. 


\section{INTRODUCTION}

Waqf is considered to be a unique Islamic economic institution that played a remarkable socio-economic role in the history of Islam and Muslims (Cizaka, 2009). Nowadays, waqf also contributes to sustainable socio-economic development (Kahf, 2007). Mohsin (2008) clarifies that waqf plays a significant social and economic role by providing education and health services, public goods (roads, bridge and national security), commercial business, utilities (water and sanitation), religious services (building and maintenance of mosque and graveyards), helping the poor, orphans and the needy, creating employment, supporting agriculture and industry while reducing the financial burden on the government.

Moreover, waqf land constitutes a large amount of the total available land in many countries, including Malaysia. According to statistics by the State Islamic Religious Councils (SIRCs), the size of waqf land in Malaysia is estimated to be around $30,888.89$ hectares, which is equivalent to 14,356 units of waqf land (YWM, 2016). According to Rashid (2011), the average rate of return on investment in developing waqf land is in the range of $20-25 \%$. However, despite its availability and potential, there is a lack of development of waqf land in Malaysia. A vast majority of research has shown that SIRCs in Malaysia face financial constraints in developing waqf land. They depend on government allocations to develop waqf land (Pitchay 2015), whereas such funding has decreased. For example, in the $9^{\text {th }}$ Malaysian Plan (RMK-9), the Malaysian government allocated RM 256 million of which RM 244 million was marked for developing 19 physical projects and RM 12 million for nonphysical projects. However, in the $10^{\text {th }}$ Malaysian Plan (RMK-10), the government's allocation has been reduced to RM 72.76 million due to economic reasons (JAWHAR, 2012; Pitchay, 2015; Thaker et al., 2017). Under RMK-10, from the 42 projects submitted, only ten were approved as physical projects from RMK-9 (Ahmad et al., 2011). Moreover, Ngah (2012) pointed out that from the total funds from RMK-9 and RMK-10, only $0.16 \%$ of waqf were developed. Whereas, in order to develop waqf land in Malaysia, SIRCs needed at least RM 80 billion (Mohd, 2012). Several studies suggested alternative models by using classical and contemporary modes of financing to develop waqf land (Çizakça 1998; Mohamad et al., 2012; Nor and Mohammed, 2009; Mohsin, 2012; Mohsin et al., 2016; Benyounis, 2015; Mohsin and Mohammad, 2011; Ali et al., 2015; Mohammad and Iman, 2006; Pitchay, 2015), however the suggestions have proven incapable of completely overcoming the issue of financial constraint in developing waqf land.

Considering the above conditions, there is a need to develop a viable model and investigate the extent to which such a model can address the issue of financial constraint and market acceptability of the donors. It can be rightly asserted that other innovative sources of financing besides government funding are required to develop waqf land in Malaysia.

\section{LITERATURE AND METHOD}

The first objective of the study is to develop a conceptual model of crowdfunding and waqf land. This study focuses on crowdfunding due to its suitability for financing waqf land development, particularly in Malaysia. Crowdfunding is a new internet-based method of fundraising in which the individual solicits contributions for projects on specialised crowdfunding websites or crowdfunding platform (CFPs) (Hemmer, 2011). In this case, crowdfunding focuses on gathering many small donations rather than requesting a single large sum from a funding agency or traditional financial institutions. A particular project is mostly funded with small contributions from a large number of individuals with the help of the internet. 
Crowdfunding, which is a computermediated means of raising funds, has gradually become an emerging paradigm to solicit funds from other individuals to execute a particular project with a social impact. In this case, the donors contribute cash donations to finance projects. Several studies stressed the utility and potential of crowdfunding to finance waqf land development (Suhaili and Palil, 2016; Al Ma'amum et al., 2016; Sabree et al., 2018). According to these studies, the proper utilisation of crowdfunding as a source of financing can upgrade, improve and enhance the capacity of waqf land in Malaysia.

The present study propose a financing model that integrates crowdfunding with waqf land development to support waqf institutions as a source of financing the development of waqf land in Malaysia. This model is developed specifically for Malaysian waqf institutions by initiating commercially viable projects. This model combines crowdfunding with waqf institutions. The present study focuses on these elements due to its potential to provide funds and support sustainable waqf development. The model validates its suitability in the market by interviewing potential donors from the field. The literature on crowdfunding claims that crowdfunding could be used to support the financing of waqf land development. As such, this study proposes crowdfunding into the waqf land development model. The model is called the crowdfunding waqf model (CWM) as illustrated in Figure 1.

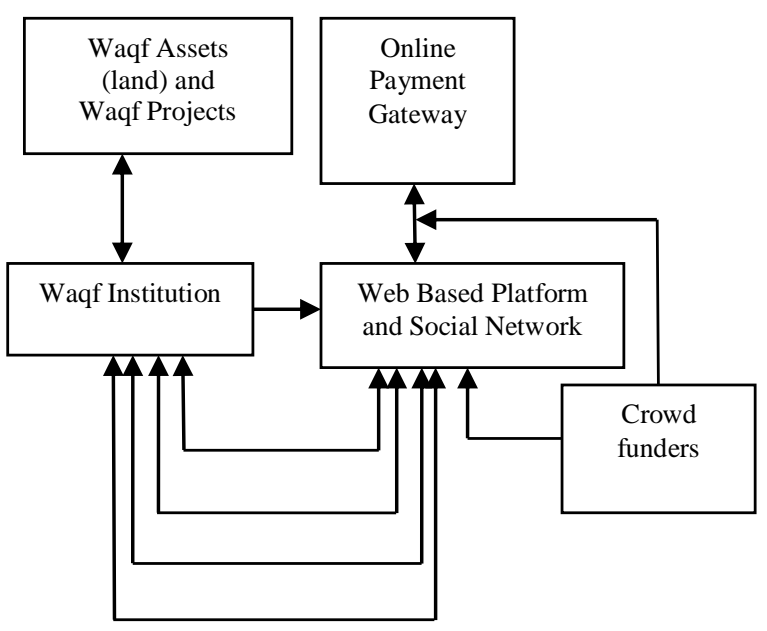

Figure 1: Crowdfunding Waqf Model (CWM)

CWM involves two the waqf institution, i.e. SIRCs or JAWHAR, and the donors or crowdfunders. The donors contribute through donation-based crowdfunding, where no rewards are given to the crowdfunders, and reward-based crowdfunding, where crowdfunders receive a tangible reward for backing the project, but not in financial form. These two types of crowdfunding are the biggest and fastestgrowing forms of crowdfunding, and will be applied in the proposed model. The donors browse the crowdfunding platform to choose the projects they are willing to support. After selecting the project, the donors transfer/send funds through payment gateways. Once the target amount of fund from the donors is reached, the system will update the status of the projects and keep track of received funds until it is ready to be distributed to waqf institutions. In the end, the waqf institution manages, monitors and supervises their funded projects and regularly updates the progress into the system until the particular projects are completed.

This model is proposed as an alternative option for financing waqf development in Malaysia. This study aims to develop a compatible model that can effectively resolve or minimise the liquidity constraints in developing waqf land in Malaysia. The model has the potential to rejuvenate waqf land in Malaysia. The use of 
crowdfunding in this model is substantial since this mode of raising initial capital has proven to be successful in Australia, United State, Netherland, United Kingdom, France, India, and Brazil, among others (World Bank, 2013).

The alternative model aims to provide financing for developing waqf land in Malaysia. This study uses primary data collected using a self-developed questionnaire containing items of different format. The formats use dichotomous answers such as "Yes" and "No" and selfassessment items measured by a Likert scale. Demographic questions are also posed to provide information on the respondent profile such as gender, age, educational level, income level and occupation. This study focuses on potential donors in four states in Malaysia, namely Pahang, Pulau Pinang, Selangor and Johor. These areas are chosen because of the availability of a waqf land database. To determine the sample size of respondents, this study applies the sample size formula provided by Yamane (1967), which is given as:

$$
n=\frac{N}{1+N(e)^{2}}
$$

Where $\mathrm{n}$ is desired sample size, $\mathrm{N}$ is the population size, and e is the level of precision or sampling error (sampling error in this study is 5\%). By applying the above formula and calculating based on $95 \%$ confidence level and 5\% error, the total desired sample size (n) is equal to 1600 . For this study, a total of 1270 respondents participated in the survey. However, only 1,000 questionnaires (79\%) are usable. The remaining $270(21 \%)$ questionnaires were incomplete and excluded from the analysis. The analysis is conducted using logistic regression. This is a nonlinear regression model designed for binary dependent variables. The purpose of this model is to test the probability of demographic of donors and the knowledge of donors in regard to crowdfunding and waqf (variables) contributes to the willingness to use CWM among donors.

Unlike a linear probability model, this model uses a nonlinear formulation that forces the predicted values to be between 0 and 1 by using cumulative probability distribution function (c.d.f.) which is denoted by F. Apart from using logit regression, probit regression could also be used in modelling binary dependent variables. The difference between logit and probit regressions is that probit regression uses the standard normal c.d.f. and logit regression uses the "logistic" c.d.f.2 (Stock and Watson, 2007). The logistic cumulative distribution function has a specific functional form defined in terms of the exponential function. The population of the logit model of the binary dependent variable $Y$ with multiple regressors could be expressed as:

$\operatorname{Pr}\left(Y=1 / X_{1}, X_{2} \ldots \ldots\right)=F\left(\beta_{0}+\beta_{1} X_{1}+\beta_{2} X_{2}+\ldots \ldots\right.$ $\left.+\beta_{n} X_{n}\right)=\frac{1}{1+e^{-(\beta 0+\beta 1 \times 1+\beta 2 X 2+\cdots+\beta n X n)}}(1)$

The main reason for using logit regression is that the logistic c.d.f. could be computed faster than the normal c.d.f. (Stock and Watson, 2007). The logistic regression model is estimated to predict a categorical (usually dichotomous) variable from a set of predictor variables. For the purpose of this study, the dependent or the outcome variable of interest was constructed as a 'yes/no' (later on coded as $1=$ yes and $0=$ no) dichotomous indicator based on the response to survey questionnaire item: "Would you willing to use Crowdfunding Waqf Model to assist waqf institution in terms of providing financing for developing waqf land?" Respondents who answered 'yes' is coded as 1 and those who answer 'no' is coded as 0 .

For predictor variables, the variables included are gender, age, marital status, educational level, occupational, monthly income level, internet usage, crowdfunding awareness and waqf awareness. All predictors are dummy variables with two 
categories. To simplify, we develop a logit model as follows:

$$
\begin{array}{rlr}
L_{i} & =\ln \left(\frac{P i}{1-P i}\right)+ & \beta_{0} \\
& +\beta_{1}(\text { DEMOGRAPHIC_VARIABLES })_{1} & + \\
& \beta_{2}(\text { INTERNET_USAGE })_{2}+{ }_{2} & \beta_{3} \\
& (\text { CROWDFUNDING_AWARENESS })_{3}+ & \beta_{4} \\
& (\text { WAQF_AWARENESS })_{4}+\varepsilon(2)
\end{array}
$$

where Li is a dummy variable with a value of 0 or 1 . $\mathrm{Li}=0$, if there is competition awareness and $\mathrm{Li}=1$ if there is no competition awareness. In the model (equation 2), if we take the antilog of the $j$ th slope coefficients ( $\beta$ 's), subtract one from it, and multiply the result by 100 , we will obtain the percentage change in the odds for a unit increase in the $j$ th regressor. The percentage change could be interpreted as the probability that the use for the model will change (increase or decrease) due to a unit increase in independent variables such as demographic and other independent variables. It is also important to note that the $R^{2}$ is a poor measure of fit for the linear and nonlinear probability model (Stock and Watson, 2007). Therefore, we use another measure of fit for this model of a binary dependent variable, namely "fraction correctly predicted". Besides, we will also perform Pearson $\chi^{2}$-type tests of goodnessof-fit (Hosmer-Lemeshow, 1989).

\section{RESULT AND DISCUSSION}

\section{Descriptive Analysis}

As depicted in Table 1, around 1000 respondents participated in this research. Based on Table 1, most of the respondents (56.7\%) were female followed by males 43.3\%. Almost three-quarters $(79.6 \%)$ of the respondents are aged between 20-40 years, and the remainder are aged over 40 years (20.4\%). The majority $(57.2 \%)$ of respondents are single, followed with $40.1 \%$ and $2.7 \%$ who are married and divorced, respectively. In terms of educational level, the majority of respondents are well educated, with almost $17.6 \%$ holding a college diploma or matriculation and about $65.6 \%$ holding at least a bachelor degree or above. Most of the respondents $(27.2 \%)$ were working in the private sector, followed with $16.9 \%$ working in the public sector. $41.5 \%$ of the respondents were students, and $3.9 \%$ were housewives. Only $2.3 \%$ of the respondents were retired. Meanwhile, the majority of respondents (61.9\%) are in the income group of less than RM3000. The remaining

\begin{tabular}{|c|c|c|c|}
\hline & & Frequency & $\%$ \\
\hline \multirow{2}{*}{ Gender } & Male & 433 & 43.3 \\
\hline & Female & 567 & 56.7 \\
\hline \multirow{4}{*}{$\begin{array}{l}\text { Age } \\
\text { Group }\end{array}$} & $20-30$ & 583 & 58.3 \\
\hline & $31-40$ & 213 & 21.3 \\
\hline & $41-50$ & 147 & 14.7 \\
\hline & Above 50 & 57 & 5.7 \\
\hline \multirow{3}{*}{$\begin{array}{l}\text { Marital } \\
\text { Status }\end{array}$} & Single & 572 & 57.2 \\
\hline & Married & 401 & 40.1 \\
\hline & Divorced & 27 & 2.7 \\
\hline \multirow{6}{*}{$\begin{array}{c}\text { Educati } \\
\text { onal } \\
\text { Level }\end{array}$} & No Education & 22 & 2.2 \\
\hline & Secondary & 146 & 14.6 \\
\hline & School & & \\
\hline & Diploma & 176 & 17.6 \\
\hline & Bachelor & 588 & 58.8 \\
\hline & $\begin{array}{l}\text { Postgraduate } \\
\text { (Master or PhD) }\end{array}$ & 68 & 6.8 \\
\hline \multirow{6}{*}{$\begin{array}{c}\text { Occupat } \\
\text { ional }\end{array}$} & Public & 169 & 16.9 \\
\hline & Private & 272 & 27.2 \\
\hline & Self employed & 82 & 8.2 \\
\hline & Housewife & 39 & 3.9 \\
\hline & Student & 415 & 41.5 \\
\hline & Retired & 23 & 2.3 \\
\hline \multirow{8}{*}{$\begin{array}{l}\text { Income } \\
\text { Level }\end{array}$} & Less than & 307 & 30.7 \\
\hline & RM1001- & 168 & 16.8 \\
\hline & RM2000 & & \\
\hline & RM2001- & 144 & 14.4 \\
\hline & RM3000 & & \\
\hline & $\begin{array}{l}\text { RM3001- } \\
\text { RM4000 }\end{array}$ & 130 & 13 \\
\hline & $\begin{array}{l}\text { RM4001- } \\
\text { RM5000 }\end{array}$ & 105 & 10.5 \\
\hline & $\begin{array}{ll}\text { More } & \text { Than } \\
\text { RM5000 } & \end{array}$ & 146 & 14.6 \\
\hline
\end{tabular}
$38.1 \%$ of the surveyed respondents have incomes higher than RM 3000.

Table 1: Distribution of Respondents by Demographic

Table 2 shows that more than half of the respondents $(68.6 \%)$ have interacted with the internet for more than six years, with 
one-third having used the internet for more than ten years. On the other hand, $30 \%$ of respondents have used the internet for less than five years. Thus, from the findings of the current study, most respondents are familiar with the internet. This indicates that the fast development of information technology has influenced almost all aspects of human life. Furthermore, according to internet proficiency, $57 \%$ of the respondents can operate the internet with moderate capability. The remaining $37 \%$ of respondents have high internet proficiency and only $5.8 \%$ have low internet proficiency. This reflects that most respondents in the current study are proficient using computers and internet technology. In terms of online activity, $67 \%$ of the respondents used the internet to access websites and emails. 78\% have been interacting with social media for 1-10 years, $18 \%$ have been using social media for more than ten years. A possible explanation for this phenomenon is that the majority of respondents are younger and are often portrayed as a generation defined by its love for the internet and social media. Thus, it indicates that most respondents are familiar with internet services.

Table 2: Internet Usage

\begin{tabular}{lccc}
\hline & & Frequency & Percent \\
\hline No. of & Less than 1 & 39 & 3.9 \\
Time in & year & 275 & 27.5 \\
Using & 1-5 years & 375 & 37.5 \\
Internet & 6-10 years & 311 & 31.1 \\
& More than & & \\
& 10 years & & \\
\hline Internet & Low & 58 & 5.8 \\
Proficienc & moderate & 570 & 57.0 \\
y & high & 372 & 37.2 \\
\hline Internet & Websites & 238 & 23.8 \\
Service & Emails & 93 & 9.3 \\
& Websites & 669 & 66.9 \\
& and Emails & & \\
\hline Social & Less than 1 & 43 & 4.3 \\
Networki & year & 431 & 43.1 \\
ng & 1-5 years & 349 & 34.9 \\
& 6-10 years & 177 & 17.7 \\
& More than & & \\
& 10 years & & \\
\hline
\end{tabular}

The respondents were asked whether or not they are aware of crowdfunding. Table 3 shows that $617(61.7 \%)$ respondents acknowledged that they are aware of crowdfunding. This could be attributed to the massive publicity of crowdfunding in online and offline media. Moreover, Table 3 reveals that the majority of respondents (54.6\%) reported being aware of donationbased crowdfunding compared to the other three types of crowdfunding (reward-based, lending-based and equity-based) each of which recorded percentages below $17 \%$.

Table 3: Awareness of Crowdfunding

\begin{tabular}{lccc}
\hline & & Frequency & Percent \\
\hline Crowdfunding & No & 383 & 38.3 \\
Awareness & Yes & 617 & 61.7 \\
\hline Type of & Donation & 546 & 54.6 \\
Crowdfunding & Reward & 156 & 15.6 \\
& Lending & 164 & 16.4 \\
& Equity & 134 & 13.4 \\
\hline
\end{tabular}

In regard to waqf land awareness, Table 4 shows that 889 (88.9\%) respondents acknowledged that they are aware of waqf land. This could be attributed to the extensive publicity and interest about waqf land raised in the mosque, and many kinds of media.

Table 4: Awareness of Waqf Land

\begin{tabular}{|c|c|c|}
\hline \multicolumn{3}{|c|}{ Frequency Percent } \\
\hline $\begin{array}{l}\text { Awareness of waqf Yes } \\
\text { Land }\end{array}$ & 889 & 88.9 \\
\hline No & 111 & 11.1 \\
\hline
\end{tabular}

The respondents were asked if they are willing to use CWM as a viable model of financing the development of waqf land in Malaysia. It can be seen from Table 5 that, out of 1000 respondents who answered the question, 689 (68.9\%) agreed, while 311 (31.1\%) did not. This indicates that that majority of respondents are ready to use the CWM to fund waqf land development. 
Table 5: Willingness to Use CWM

\begin{tabular}{|c|c|c|c|}
\hline \multicolumn{4}{|c|}{ Frequency Percent } \\
\hline \multirow{2}{*}{$\begin{array}{l}\text { Willingness to use } \\
\text { CWM }\end{array}$} & Yes & 689 & 68.9 \\
\hline & No & 311 & 31.1 \\
\hline
\end{tabular}

\section{Empirical Analysis}

Table 6 shows the logistic regression coefficients based on equation (2), Wald test and odds ratio for each predictor. The odds ratio is abbreviated as Exp (B). an Exp (B) and is greater than 1 implying that the independent variable increases the logit and therefore increases the odds (event). If Exp (B) is equal to 1 , the independent variable has no effect. And, if $\operatorname{Exp}(\mathrm{B})$ is less than 1.0, then the independent variable decreases the logit and decreases odds (event). With regard to the logit model estimated coefficients; a positive regression coefficient indicates that the explanatory variable increases the log-odds of the outcome, while a negative regression coefficient means that the predictor variable decreases the logodds of that outcome. In this case, a negative coefficient will produce an odds ratio between the range of 0 to 1 and a positive coefficient will result in an odds ratio greater than 1.
Table 6 Logistic Regression

\begin{tabular}{|c|c|c|c|}
\hline \multirow{3}{*}{$\begin{array}{l}\text { Independent } \\
\text { Variable }\end{array}$} & \multicolumn{3}{|c|}{ Binary Logistic } \\
\hline & \multicolumn{3}{|c|}{$\begin{array}{c}\text { Dependent Variable: } \\
\text { Willingness to Use CWM }\end{array}$} \\
\hline & $B$ & Sig. & $\operatorname{Exp}(B)$ \\
\hline Dummy Gender & .461 & .002 & 1.586 \\
\hline Dummy Age & .046 & .824 & 1.047 \\
\hline $\begin{array}{l}\text { Dummy } \\
\text { Marital_Status }\end{array}$ & .532 & .004 & 1.703 \\
\hline $\begin{array}{l}\text { Dummy } \\
\text { Educational_Level }\end{array}$ & .179 & .374 & 1.196 \\
\hline $\begin{array}{l}\text { Dummy } \\
\text { Occupation }\end{array}$ & .057 & .745 & 1.059 \\
\hline $\begin{array}{l}\text { Dummy } \\
\text { Monthly_Income }\end{array}$ & -.408 & .015 & .665 \\
\hline $\begin{array}{l}\text { Dummy } \\
\text { InternetUsage }\end{array}$ & -.232 & .158 & .793 \\
\hline $\begin{array}{l}\text { Dummy } \\
\text { Crowd_Knowledge }\end{array}$ & .352 & .016 & 1.423 \\
\hline $\begin{array}{l}\text { Dummy } \\
\text { Waqf_Knowledge }\end{array}$ & .470 & .029 & 1.600 \\
\hline Constant & -.110 & .749 & .896 \\
\hline $\begin{array}{l}\text { \% of Correct } \\
\text { Observation }\end{array}$ & & & 68.4 \\
\hline $\begin{array}{l}\text { Omnibus Chi-sq } \\
\text { Stat. }\end{array}$ & & (sig & $.000)$ \\
\hline $\begin{array}{l}\text { Hosmer and } \\
\text { Lomeshow Test } \\
\text { stat. }\end{array}$ & & 16 (sig. & $=0.657)$ \\
\hline $\begin{array}{l}\text { Cox and Snell R- } \\
s q\end{array}$ & & & 0.046 \\
\hline Nagelkerke R-sq & & & 0.065 \\
\hline
\end{tabular}

Note: Standard errors are in parentheses; statistically significant at the $5 \%$ level

The insignificant independent variables are "Age", "Educational Level", "Occupation" and "Internet Usage". Other variables are significant at the $5 \%$ level. Variables "Gender", "Marital Status", "Monthly Income", "Crowd_Knowledge", and "Waqf Land Knowledge" positively and significantly affect the probability willingness to use the Crowdfunding Waqf Model (CWM). Females dominate this model 
use with the odds of 1.586 times higher compared to males. The non-married respondents have the odds of answering yes (use for the model) 1.703 times higher than those who are married. The odds of selecting the CWM is 1.423 times higher for respondents who are aware of crowdfunding than for respondents unaware of crowdfunding, all other factors being equal. The odds of selecting the model is also 1.600 times higher for respondents who are aware of waqf than those who are not, other factors being constant. The coefficient of the variable monthly income is significant at the level of $5 \%$ with a negative sign in the coefficient. This condition implies that variable indicator which is denoted by 0 will be over the indicator denoted by 1 in that particular analysis. A negative value of $B$ for the dummy of monthly income level indicates that respondents with a higher monthly income are less likely to use the CWM compared to respondents with less monthly income. The respondents who have higher monthly income, the odds of them to select crowdfunding waqf model decrease by the factor of 0.665 , all other factors being equal. Thus, from the findings, the highest probability to use crowdfunding waqf model is when non-married female respondents do it with low-middle monthly incomes and are aware of crowdfunding and waqf. The lowest probability is reached by married male respondents with high monthly incomes and are unaware of crowdfunding and waqf.

As for the diagnostic tests, the model as a whole explains between $0.4 \%$ (Cox \& Snell R2) and $0.6 \%$ (Negelkerke R2) of the variance in competition awareness and correctly classified $68.4 \%$ of cases. Hosmer \& Lemeshow test statistic supports the model as being worthwhile. The Chi-square value for the test is 5.96, with a significance value of 0.657 . Since the significance value is larger than $0.05(5 \%)$, the model fits the data very well.

\section{CONCLUSION AND IMPLICATION}

The motivation of the study arises out of the concern for the current state of Malaysian waqf land development. For waqf institutions, raising funds to develop waqf lands is very important. However, based on empirical evidence, waqf institutions face many constraints, particularly concerning liquidity or shortage of funds. The objectives of the study are to analyse an alternative source of financing to develop a new model of financing through crowdfunding waqf model and analyse the probability that waqf institutions will use the proposed model.

Based on the responses received from the field, the willingness and readiness of donors in assisting Waqf institutions in Malaysia to develop waqf land by donating via the crowdfunding platform is impressive. The findings support a high probability of respondents to use the proposed crowdfunding waqf model to develop waqf land in Malaysia contributed by young and unmarried donors with monthly income, but who are aware of crowdfunding and waqf. Based on the findings, the government and relevant agencies are recommended to explore the use of alternative funding for waqf land development such as crowdfunding and others. If the government plan to use the proposed crowdfunding waqf model, there is a high probability that the model will be accepted successfully by those who are young and unmarried as well as among lowmiddle income donors.

\section{REFERENCES}

Ahmad, S., \& Muhamed, N. D. (2011). Wakaf Institutions and National Economic Development: A Case on Wakaf Land Development in Malaysia. Prosiding Perkem VI, Jilid 1, (pp. 139-147).

Al Ma'amun, Suhaili and Shafiai, M. Hakimi Mohd, and Adnan, M. S. A. (2016). Waqfworld when Waqf Meets Crowdfunding in Islamic Finance Today (Asiff Hussein: editor). 
Colombo, Sri Lanka: Pioneer Publication.

Benyounis, Husain. (2015). Why There Is A Need To Engineer The Awqaf Industry: Awqaf NZ Experiece. A presentation at International Centre for Waqf Research (ICWR) Monthly Waqf Talk Series. 18 September 2015.

Çizakça, Murat. (1998). Awqaf In History and Its Implications for Modern Islamic Economies. Islamic Economic Studies: Vol. 6, No. 1, November 1998.

Cizakca, M. (2009). Incorporated Cash Waqfs: Islamic Non-Banking Financial Instruments form the Past to the Future. INCIEF, 16.

Hemer, Joachim (2011). A Snapshot on Crowdfunding. Working Papers Firms and Region, No. R2/2011, ISSN 1438-9843.

Hosmer, D.W. and Lemeshow, S. (1989). Applied Logistic Regression. John Wiley \& Sons, Inc., New York.

JAWHAR. (2012). Jabatan Waqaf, Zakat dan Haji.

http://119.110.108.126/spmwj/. http://www.jawhar.gov.my/iwakaf.

Kahf, M. (2007). The Role of Waqf in Improving the Ummah Welfare. Singapore International Waqf Conference 2007 on 6-7 March 2007., (p. 2). The Fullerton Hotel Singapore.

Mohamad, N. A., Kader, S. Z. S. A., \& Ali, Z. (2012). Waqf Lands and Challenges From the Legal Perspectives in Malaysia. IIUM -Toyo Symposium 2012. Sustainable Built Environment : Lessom Learned from Malaysia and Japan, 1993(Act 505).

Mohammad, M. T. S. and Iman. (2006). Obstacles of the Current Concept of Waqf to the Development of Waqf Properties and the Recommended
Alternative. Malaysian Journal of Real Estate 1 (1), 27-38

Mohd, Datuk Haji Anan bin C. (2012). Mohd, Datuk Haji Anan bin C. (2012). Negeri Sembilan: Seminar Peletakhakan Tanah Wakaf : Cabaran dan Harapan pada 25-27 April 2012

Mohsin, Magda. I. (2008). Current Application of Cash-Waqf- The Social and Economic Empowerment of the Ummah. International Seminar on Awqaf 2008. Johor Bharu.

Mohsin, M I. (2012). Waqf-Shares: new product to finance old waqf properties. Banks and Bank Systems (open-access), 7(2. Banks and Bank Systems, Volume 7, Issue 2, 2012.

Mohsin, M.I. (2013). Financing through cash-Waqf: A Revitalisation to Finance different needs. International Journal of Islamic and Middle Eastern Finance and Management. Vol.6.No.4, pp.304-321

Mohsin, M. I. A., Dafterdar H, Cizakca M., Alhabshi S. O., Razak S. H. A., Sadr S. K., Anwar T., and Obaidullah M. (2016). Financing the Development of Old Waqf Properties.

Ngah, N. (2012), December Monday, 25 October, available at: www.jawhar.gov.my/index.php/ms/ akhbar/123-artikel-bh25102012.

Nor, Norhaliza B. M. and Mohammed, Mustafa O. (2009). Categorization of Waqf Lands and their Management Using Islamic Investment Models: the Case of the State of Selangor, Malaysia. Paper presented at the International Conference on Waqf Laws \& Management: reality and Prospects, IIUM, 20-22 October 2009.

Pitchay, Anwar bin Allah. (2015). The Role of Cash waqf in Rejuvenation of Malaysian Waqf Assets. Unpublished PhD Dissertation: International Islamic University Malaysia 
Pitchay, A. A., Kameel, A., Meera, M., \& Saleem, M. Y. (2015). Factors Influencing the Behavioral Intentions of Muslim Employees to Contribute to Cash- Waqf Through Salary Deductions. Journal of King Abdulaziz University: Islamic Economics, 28(1), 63-98.

Rashid, S. K. (2012). Certain legal and administrative measures for revival and better management of awqaf (Unpublished).

Sabree, Ahmad, Munshi, Umar, and Chignell, R. A. (2018). Combining Fintech, Crowdfunding And Cash Waqf to Create Sustainable Charity: The Case Of Waqf World Growth Foundation in Islamic Commercial Law Report 2018. Kuala Lumpur: ISRA, Thomson Reuters and IRTI publication.

Stock, James \& Mark Watson. (2007) Introduction to Econometrics, Boston: Pearson Education Inc.

Suhaili, Nur Aqidah \& Mohd Rizal Palil. (2016). Crowdfunding: A Collaborative Waqf Based Internet Platform. International Journal of Business, Economics and Law, Vol. 11, Issue 5 (Dec.) Issn 2289-1552.

Thaker, Mohamed Asmy bin Mohd Thas. \& Hassanudin Bin Mohd Thas Thaker (2017). Innovative Financing of Equity Crowdfunding: Application On Waqf Land. International Islamic Fund and Wealth Management Forum (IIFWMF) -Organized by The IiBF in Collaboration With The PNB.

World Bank (2013). Crowdfunding's Potential For The Developing World. infoDev, Finance and Private Sector Development Department, Washington DC.

Yamane, Taro. (1967). Statistics, An Introductory Analysis (2nd Edn.). New York: Harper and Row.

YWM (Yayasan Wakaf Malaysia). (2016). Waqf Development Transformation
Master Plan Study in Malaysia (General Edition). Selangor: Firdaus Press Sdn Bhd 